Research Article

\title{
Application of Residual Shear Strength Predicted by Artificial Neural Network Model for Evaluating Liquefaction-Induced Lateral Spreading
}

\author{
Yanxin Yang $\mathbb{D}^{1},{ }^{1}$ Bai Yang $\mathbb{D},{ }^{1,2}$ Chunhui $S u,{ }^{1}$ and Jianlin $\mathrm{Ma}^{2}$ \\ ${ }^{1}$ School of Architecture and Transportation Engineering, Guilin University of Electronic Technology, Guilin, \\ Guangxi 541004, China \\ ${ }^{2}$ School of Civil Engineering, Southwest Jiaotong University, Chengdu, Sichuan 610031, China
}

Correspondence should be addressed to Bai Yang; ayangbai@163.com

Received 7 April 2020; Revised 3 July 2020; Accepted 14 July 2020; Published 7 August 2020

Academic Editor: Ali R. Vosoughi

Copyright (C) 2020 Yanxin Yang et al. This is an open access article distributed under the Creative Commons Attribution License, which permits unrestricted use, distribution, and reproduction in any medium, provided the original work is properly cited.

The residual shear strength of liquefied soil is critical to estimating the displacement of lateral spreading. In the paper, an Artificial Neural Network model was trained to predict the residual shear strength ratio based on the case histories of lateral spreading. High-quality case histories were analyzed with Newmark sliding block method. The Artificial Neural Network model was used to predict the residual shear strength of liquefied soil, and the post-liquefaction yield acceleration corresponding with the residual shear strength was obtained by conducting limit equilibrium analysis. Comparing the predicted residual shear strength ratios to the recorded values for different case histories, the correlation coefficient, $R$, was 0.92 and the mean squared error (MSE) was 0.001 for the predictions by the Artificial Neural Network model. Comparison between the predicted and reported lateral spreading for each high-quality case history was made. The results showed that the probability of the lateral spreading calculated with the Newmark sliding block method using the residual shear strength was $98 \%$ if a lateral spreading ratio of 2.0 was expected and a truncated distribution was used. An exponential relationship was proposed to correlate the residual shear strength ratio to the equivalent clean sand corrected SPT blow count of the liquefied soil.

\section{Introduction}

Liquefaction is the phenomenon whereby saturated sandy soil behaves like a liquid during the shaking by earthquakes. In the saturated sandy soil, the strength of the soil is lost when the pore water pressure builds up and approaches the total pressure due to the cyclic shear loading. During the past earthquakes, widespread damage caused by liquefaction includes the damage to buildings, pipelines, coastal slopes, and the ground deformations.

The limited deformation of gently sloping ground is defined as lateral spreading. To adopt proper mitigation measures, the displacement magnitude of lateral spreading needs to be determined. The residual shear strength, which corresponds to the minimum shear strength at which the lateral spreading is mobilized, is one of the main factors to determine the lateral spreading induced by seismic liquefaction.

Several methods have been proposed to estimate the residual strength of liquefied soil based on the back-calculation of the case histories or laboratory tests. Compared to the laboratory test, the case histories make it possible to consider the effect of voids redistribution, inertial effect, geometry effect, and the other factors on the residual shear strength of liquefied soil, so the method estimating the residual shear strength back-calculated from the case histories is widely used in the seismic displacement calculation and stability analysis of the level or sloping ground.

There are disadvantages when utilizing the residual shear strength relationship developed from case histories. As the development of the estimation methods is based on in-site investigation and the soil resistance parameters (Standard 
Penetration Test or Cone Penetration Test values of the liquefiable soil) of case histories, the limited number of the case histories will result in the uncertainties in estimating the residual shear strength. On the other hand, the back-calculation of residual shear strength is depending on the case histories of flow failures, initially proposed by Seed [1] and then modified by the other researchers. The displacement of flow failures can be more than several meters as the soil above the liquefied soil is still moving even after the earthquake stops. The postliquefaction residual shear strength of the liquefied soil is smaller than the driving force provided by the static stress. Regarding the lateral spreading, the postliquefaction residual shear strength is usually greater than the static driving force, so the movement of the soil above the liquefied soil will cease once the earthquake stops. It may not be appropriate to use the residual shear strength of liquefied soil derived from the case histories of flow failures to calculate the residual shear strength of liquefied soil at the lateral spreading sites. Although Olson and Johnson [2] stated that "lateral spreads back analyzed using the Newmark sliding block procedure exhibit mobilized strength ratios essentially identical to liquefied strength ratios back calculated from flow failures," the residual shear strength of liquefied soil in the lateral spreading cases needs to be evaluated carefully for assessing the deformation of lateral spreading in different analyses such as limit equilibrium analysis, finite difference analysis, or finite element analysis.

Recently, the Artificial Intelligence techniques, such as Artificial Neural Network [3], Support Vector Machine [4], and Genetic Programming [5], have been used in different fields of engineering. Among these Artificial Intelligence techniques, Artificial Neural Network is a powerful tool to describe the relationship between the residual shear strength and soil resistance parameters. By training the data given to the training system, the Artificial Neural Network will identify the relationship between the input and output variables.

When the residual shear strength of liquefied soil, which is corresponding with the minimum strength that the lateral spreading is mobilized, is determined, a postliquefaction yield acceleration using the residual shear strength could be obtained. As the lateral spreading is the horizontal displacement of soil underlain by liquefied soil after the triggering of liquefaction, the displacement of lateral spreading can be calculated with Newmark sliding block method. The mechanism of liquefaction-induced lateral spreading can be described as follows: The downslope displacement accumulates when the seismic force is oriented to downslope direction, and the liquefied soil retains the residual shear strength during the accumulation of the displacement. The failure is driven by the combined static shear stress and the seismic force, which is greater than the residual shear strength, while the static stress is less than the residual shear strength, so the displacement of lateral spreading ceases when the earthquake ends. Such an accumulation of displacement can be calculated by the Newmark sliding block method if the soil above the liquefied soil is treated as a rigid block and it slides over the sliding surface existing in the liquefied soil. Despite that the application of the Newmark sliding block method in lateral spreading has been proposed and conducted by Baziar et al. [6], Taboada et al. [7], and Kavazanjian [8], systematic research on its application by analyzing more case histories of lateral spreading is needed.

In this paper, firstly, the Artificial Neural Network model was trained to predict the residual shear strength ratio (the ratio of residual shear strength to the effective shear stress) in terms of equivalent clean sand corrected SPT value of the liquefiable soil. A database of lateral spreading was used for training the neurons to recognize the patterns between the residual shear strength ratio and equivalent clean sand corrected SPT blow count of the liquefied sand. The statistical performance of the model was evaluated based on the two parameters including correlation coefficient, $R$, and mean square error (MSE). The cumulative probabilities were calculated for different ratios (i.e., the ratio of the predicted residual shear strength to the observed residual shear strength). By computing the root mean square error (RMSE), the Artificial Neural Network model was compared with the Olson and Johnson model [2]. A high-quality database of lateral spreading was established based on the case histories used in the process of training the Artificial Neural Network model. The residual shear strength predicted by the Artificial Neural Network model for highquality case histories of lateral spreading was subsequently analyzed in the limit equilibrium analysis [9] to obtain postliquefaction yield acceleration. The Newmark sliding block analysis implemented in a computer code (SLAMMER) [10] was conducted for high-quality case histories. By applying a truncated normal distribution to describe the distribution of lateral spreading ratio (the ratio of predicted lateral spreading to observed lateral spreading), a statistical analysis was conducted to evaluate the accuracy of the Newmark sliding block method. Based on the residual shear strength values of the high-quality case histories, an exponential equation was proposed to represent the relationship between the residual shear strength ratio and the equivalent clean sand corrected SPT blow count of the liquefied soil.

1.1. Residual Shear Strength of Liquefied Soil. The residual shear strength of liquefied sand could be estimated by empirical models based on the SPT (Standard Penetration Test) blow counts of the soil. Seed [1] back-analyzed limited cases of liquefaction flow failures. The available residual shear strengths of liquefied sand and equivalent clean sand $\left(N_{1}\right)_{60-c s}$ values were summarized, and a relationship between the residual shear strength and equivalent clean sand $\left(N_{1}\right)_{60-c s}$ values was proposed in a form of a chart. Seed and Harder [11] updated the chart of Seed [1], and with more case histories data put in the database, the inertial effects were taken into consideration in the back-analysis. The relationship based on field data provides an estimation of the undrained shear strength of liquefied sands by Standard Penetration Test corrected blow count, with an upper bound and a lower bound of residual shear strength for the specific $\left(N_{1}\right)_{60-c s}$ value. Idriss [12] proposed a relationship between the undrained residual shear strength and equivalent clean 
sand corrected SPT blow count by modifying the database of Seed and Harbor [11]. The relationship was expressed in terms of a single exponential curve, the residual shear strength could be obtained from a specific SPT value, and error bars were used for indicating the uncertainty in calculating residual shear strength. Stark and Mersi [13] defined the ratio of back-calculated residual shear strength to the initial vertical effective stress as $S_{r} / \sigma_{v o}$ for 20 case histories and developed the ratio as a function of SPT blow count. Olson and Stark [14] updated the database with more casehistory data and expressed the residual shear strength ratio as a function of equivalent clean sand corrected SPT blow count $\left(N_{1}\right)_{60}$ and CPT resistance $q_{\mathrm{cl}}$. The fines content correction was not considered in development of the relationships. Idriss and Boulanger $[15,16]$ developed a relationship between the residual shear strength ratio $S_{\mathrm{r}} / \sigma_{\mathrm{vo}}$ and the equivalent clean sand corrected SPT blow count $\left(N_{1}\right)_{60-c s}$ using the databases of Seed [1], Seed and Harder [11], and Olson and Stark [14]. The unreliable cases were removed from the database. The relationship was expressed in a curve including two branches: one branch for the condition that the void redistribution is expected to be significant and one for the condition that void redistribution effects are expected to be negligible. Kramer and Wang $[17,18]$ developed a hybrid relationship that defined the ratio of residual shear strength to preearthquake vertical effective stress as a nonlinear function of normalized SPT resistance; the effective-stress-dependent approach combined classical and normalized strength approaches and was calibrated with the case histories of flow failures. Fines content correction was not suggested due to the lack of systematic variation in the residual shear strength with fines content. Olson and Johnson [2] back-analyzed a database consisting of 39 welldocumented lateral spreads induced by liquefaction with Newmark sliding method. The relationship between backcalculated strength ratio $S_{\mathrm{r}} / \sigma_{\mathrm{vo}}^{\prime}$ and either normalized cone penetration resistance or standard penetration resistance (with no fines content correction) was developed. Olson and Johnson [2] found that the mobilized strength ratio was independent of lateral displacement magnitude and shaking intensity. Özener [19] summarized the database of lateral spreading and proposed the estimation relationship developed from the shear wave velocity and residual shear strength ratio. As a summary, the residual shear strength can be estimated by taking account of the effective overburden stress and the soil resistance parameters such as SPT blow count and cone penetration resistance. These researches suggested that the residual shear strength was related to the soil resistance parameters (such as SPT blow count or CPT resistance value) and effective overburden stress. The effect of overburden effective stress on the residual shear strength was minimized in these researches via the use of the residual shear strength ratio.

By analyzing the reported SPT blow counts and the residual shear strength ratios for the liquefied soil from the database of lateral spreading, it provides an opportunity to investigate the residual shear strength of the liquefied soil using Artificial Neural Network model. It has to be noticed that, except for the residual shear strength relationship proposed by Olson and Johnson [2] and Özener [19], the other relationships or empirical models used to calculate the residual shear strength of liquefied soil are developed based on the case histories of flow failures. Due to the difference between residual shear strength of liquefied soil for lateral spreading and flow failures, it is more suitable to use the empirical model of residual shear strength of liquefied soil developed based on the case histories of lateral spreading solely when lateral spreading is analyzed. The variances of reported residual shear strength, the effective overburden stress, and the SPT blow count are induced by instruments and different means of measurements, which further induce the uncertainties of these parameters in the research literature. In the paper, the median values of the residual shear strengths, the effective overburden stress, and the SPT blow counts are used to minimize uncertainties and obtain the best estimation of the relationship between the residual shear strength ratio (the ratio of the residual shear strength to the effective overburden stress) and the SPT blow count.

The fines content correction equation of liquefied sand by Seed [1] is used to consider the influence of fines content on the SPT blow count and the residual shear strength. The equivalent clean sand corrected SPT blow count can be obtained in equation (1), where $\left(N_{1}\right)_{60-c s}$ is the equivalent clean sand SPT blow count and $N_{\mathrm{cr}}$ is the fines content correction for the SPT blow count recommended by Seed [1], as shown in Table 1:

$$
\left(N_{1}\right)_{60-\mathrm{cs}}=\left(N_{1}\right)_{60}+N_{\mathrm{cr}} \text {. }
$$

\section{Introduction to Artificial Neural Network}

In the field of biology, the human brain processes the information via a neural network, which is formed by billions of interconnected neurons. The Artificial Neural Network is an information system developed based on the informationprocessing characteristics of the human brain. In Figure 1, the structure of an Artificial Neural Network with two hidden layers is shown. The hidden pattern between the input and the output layers can be described in different forms by introducing the hidden layers. The values of the input variables are represented by the input layer, and the response of the Artificial Neural Network is represented by the output layer. The hidden layer includes the weights of input variables, the biases, and the transfer functions, responsible for training the interconnected neurons and recognizing the relationship between the input layer and the output layer. By using the transfer functions, the input weight is obtained by a trial-and-error procedure when the predicted output is approaching the observed output, and the coverages reach a local or global optimum. An error function needs to be minimized during the learning process to avoid overfitting of the variable weight. After the training is finished, the Artificial Neural Network can be tested with a set of test data.

In this paper, a two-layer feedforward neural network with sigmoid hidden neurons and linear output neurons [20] is used. A total of 39 hidden neurons are used. A Bayesian regularization method is used as a backpropagation 
Table 1: $N_{\mathrm{cr}}$ for fines content.

\begin{tabular}{lcccc}
\hline Fines content (passing No. 200 sieve) & $10 \%$ & $25 \%$ & $50 \%$ & $75 \%$ \\
\hline$N_{\mathrm{cr}}$ & 1 & 2 & 4 & 5 \\
\hline
\end{tabular}

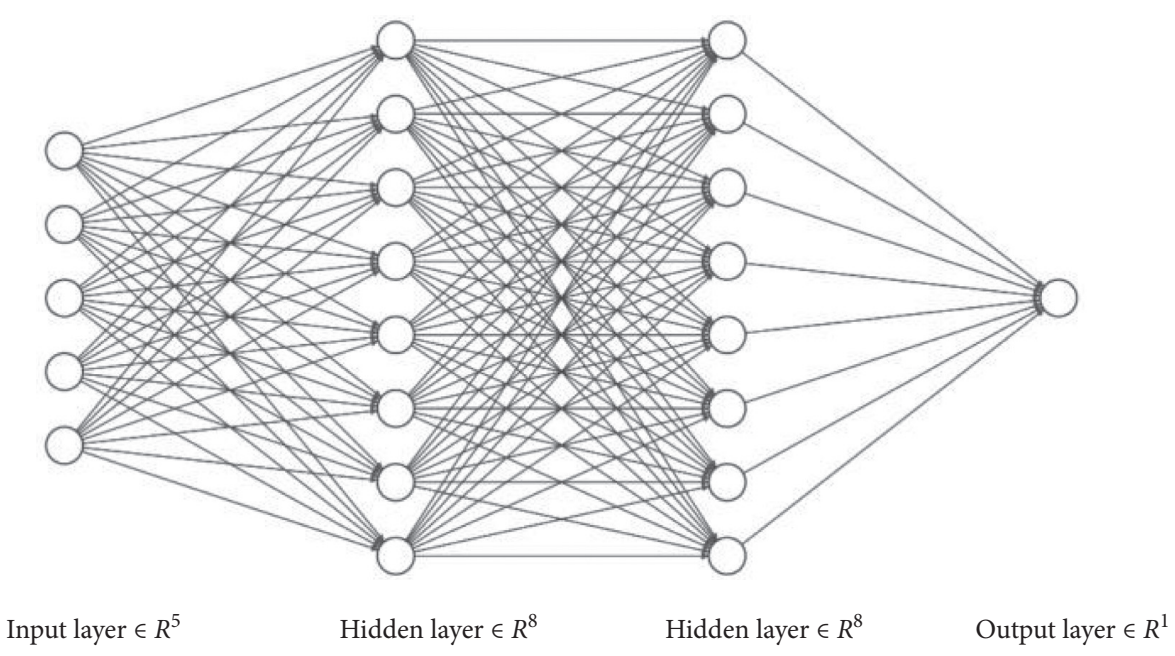

Figure 1: Illustration of Artificial Neural Network.

algorithm, which requires a solution to a Hessian matrix. An objective function incorporating parameters $\alpha$ and $\beta$ and a function consisting of the mean square error of weights and biases are used to realize the regularization [21]. In equation (2), the objective function is expressed, where $\alpha$ and $\beta$ are objective function parameters. The parameters $\alpha$ and $\beta$ are computed using Gauss-Newton approximation of the Hessian matrix of the objective function in Bayesian framework:

$$
F=\alpha E_{\mathrm{W}}+\beta E_{\mathrm{D}}
$$

where $E_{\mathrm{W}}$ is the function consisting of the mean square error of weights and biases and it is expressed in equation (3), where $w_{i}$ is the variable weight and $M$ is the number of interconnected neurons:

$$
E_{\mathrm{W}}=\frac{1}{M} \sum_{i=1}^{M} w_{i}^{2}
$$

where $E_{\mathrm{D}}$ is the sum of squared errors between the target value and the output value generated by the neural network, which is expressed in equation (4), where $y_{i}$ is the target value and $\widehat{y}_{i}$ is the output value generated by the neural network:

$$
E_{\mathrm{D}}=\sum_{i=1}^{M} \frac{1}{2}\left(y_{i}-\widehat{y}_{i}\right)^{2}
$$

2.1. Case Histories of Liquefied Sand in Lateral Spreading and Artificial Neural Network Results. The case histories from the different research literature, which are also reported by
Olson and Johnson [2] and Özener [19], are used to develop the database for developing and training an Artificial Neural Network model. Referring to the initial research literature for each case history, a total of 43 records were used. Among the 43 case histories, 35 records were used for training the model, 4 records were used for validation, and the rest of records were used for testing the model. The residual shear strength ratio and SPT blow count of the liquefied soil were used as input variables. In Table 2, for each case history of lateral spreading, the earthquake event, site location, residual shear strength ratio, SPT blow count of liquefied soil, fines content, median residual shear strength ratio of the liquefied soil, and the equivalent clean sand corrected SPT blow count of liquefied soil for each case history reported by the literature research are summarized. The references used for summarization are also listed in Table 2. The SPT blow count of the liquefied soil was corrected to equivalent clean sand corrected SPT blow count based on the Seed relationship [1] shown in equation (1). For equivalent clean sand corrected SPT blow count, the maximum value, minimum value, average value, and the standard deviation value are $21,2.7$, 11.1, and 3.7, respectively. The maximum value, minimum value, average value, and the standard deviation values of the residual shear strength ratios are $0.75,0.02,0.11$, and 0.11 , respectively.

In Figure 2, the observed and predicted values of residual shear strength ratios are shown to illustrate the performance of the proposed Artificial Neural Network model. The correlation coefficient, $R$, is 0.92 and the mean squared error (MSE) is 0.001 for the training results. In (5), the mean square error is expressed: 
TABLE 2: Case histories of lateral spreading used for training Artificial Neural Network model.

\begin{tabular}{|c|c|c|c|c|c|c|c|c|}
\hline $\begin{array}{l}\text { Case } \\
\text { no. }\end{array}$ & $\begin{array}{l}\text { Location of } \\
\text { lateral spreading }\end{array}$ & $\begin{array}{l}\text { Earthquake } \\
\text { event }\end{array}$ & $\begin{array}{l}\text { Residual } \\
\text { shear } \\
\text { strength } \\
\text { ratio }\end{array}$ & $\begin{array}{l}\text { SPT } \\
\text { blow } \\
\text { count }\end{array}$ & $\begin{array}{l}\text { Fines } \\
\text { content } \\
(\%)\end{array}$ & $\begin{array}{l}\text { Median } \\
\text { residual } \\
\text { shear } \\
\text { strength } \\
\text { ratio }\end{array}$ & $\begin{array}{l}\text { Equivalent } \\
\text { clean sand } \\
\text { blow count }\end{array}$ & Reference \\
\hline 1 & Heber road & $\begin{array}{l}1979 \text { Imperial } \\
\text { Valley }\end{array}$ & $0.03-0.12$ & 1.0 & 20 & 0.075 & 2.7 & $\begin{array}{c}\text { Davis et al. [22]; Castro } \\
\text { [23]; Youd and Bennett } \\
\text { [24]; Olson and Johnson } \\
\text { [2]; Özener [19] }\end{array}$ \\
\hline 2 & Wildlife site & $\begin{array}{l}1987 \\
\text { Superstition } \\
\text { Hills }\end{array}$ & $0.06-0.10$ & 10.3 & 30 & 0.08 & 12.7 & $\begin{array}{l}\text { Holzer et al. [25]; } \\
\text { Boulanger et al. [26]; Idriss } \\
\text { and Boulanger [27]; Olson } \\
\text { and Johnson [2]; Özener } \\
\text { [19] }\end{array}$ \\
\hline 3 & $\begin{array}{l}\text { Moss Landing, } \\
\text { MBARI Bldg. 4, } \\
\text { Sandholdt rd. } \\
\text { (SI-2) }\end{array}$ & & $0.14-0.19$ & 10.0 & 5 & 0.17 & 10.5 & $\begin{array}{c}\text { Boulanger et al. [28]; Olson } \\
\text { and Johnson [2]; Özener } \\
{[19]}\end{array}$ \\
\hline 4 & $\begin{array}{l}\text { Moss Landing, } \\
\text { MBARI Bldg. 4, } \\
\text { Sandholdt rd. } \\
\text { (SI-5) }\end{array}$ & & $0.11-0.19$ & 15 & $<5$ & 0.15 & 15.0 & $\begin{array}{c}\text { Boulanger et al. [28]; Olson } \\
\text { and Johnson [2]; Özener } \\
{[19]}\end{array}$ \\
\hline 5 & $\begin{array}{l}\text { Moss Landing, } \\
\text { MLML Bldg., } \\
\text { westward spread }\end{array}$ & $\begin{array}{l}1989 \text { Loma } \\
\text { Prieta }\end{array}$ & $0.06-0.14$ & 14.6 & 4 & 0.1 & 15.0 & $\begin{array}{l}\text { Mejia [29]; Olson and } \\
\text { Johnson [2]; Özener [19] }\end{array}$ \\
\hline 6 & Marina District & & $0.06-0.08$ & 10.5 & $14-41$ & 0.07 & 12.7 & $\begin{array}{c}\text { Olson and Johnson [2]; } \\
\text { Özener [19] }\end{array}$ \\
\hline 7 & Miller Farm & & $0.05-0.16$ & 11.5 & $5-38$ & 0.11 & 13.3 & $\begin{array}{c}\text { Holzer et al. [30]; Olson } \\
\text { and Johnson [2]; Özener } \\
{[19]}\end{array}$ \\
\hline 8 & $\begin{array}{l}\text { Treasure Island, } \\
\text { Perimeter } \\
\text { (T1N3) }\end{array}$ & & $0.07-0.22$ & 10.0 & 10 & 0.15 & 11.0 & $\begin{array}{c}\text { Power et al. [31]; Olson and } \\
\text { Johnson [2]; Özener [19] }\end{array}$ \\
\hline 9 & $\begin{array}{c}\text { Magsaysay } \\
\text { Bridge E. Bank, } \\
\text { u/s (DD) } \\
\text { Magsavsay }\end{array}$ & $\begin{array}{l}1990 \text { Luzon, } \\
\text { Philinnines }\end{array}$ & $0.02-0.06$ & 6 & $15-20$ & 0.04 & 7.5 & $\begin{array}{c}\text { Ishihara et al. [32]; Özener } \\
\text { [19] }\end{array}$ \\
\hline 10 & $\begin{array}{c}\text { Magsaysay } \\
\text { Bridge E. Bank, } \\
\text { u/s (EE) }\end{array}$ & Philippines & $0.03-0.09$ & 9 & $15-20$ & 0.06 & 9.5 & $\begin{array}{c}\text { Ishihara et al. [32]; Özener } \\
\text { [19] }\end{array}$ \\
\hline 11 & Hotel Sapanca & & $0.05-0.11$ & 13.4 & 6.2 & 0.08 & 7.0 & $\begin{array}{c}\text { Cetin et al. [33]; Özener } \\
{[19]}\end{array}$ \\
\hline 12 & Police station & 1999 Kocaeli, & $0.07-0.10$ & 5 & 24.55 & 0.09 & 7.0 & $\begin{array}{c}\text { Cetin et al. [33]; Özener } \\
{[19]}\end{array}$ \\
\hline 13 & Soccer field & Turkey & $0.05-0.10$ & 7 & 34 & 0.08 & 9.7 & $\begin{array}{c}\text { Cetin et al. [33]; Özener } \\
\text { [19] }\end{array}$ \\
\hline 14 & Yalova Harbor & & $0.14-0.20$ & 14.53 & 20.8 & 0.17 & 16.3 & $\begin{array}{c}\text { Cetin et al. [33]; Özener } \\
{[19]}\end{array}$ \\
\hline 15 & $\begin{array}{l}\text { Wufeng site C } \\
\qquad\left(A-A^{\prime}\right)\end{array}$ & & $0.05-0.12$ & 3.5 & 25.5 & 0.09 & 6.5 & Chu et al. [34]; Özener[19] \\
\hline 16 & $\begin{array}{l}\text { Wufeng site } \mathrm{C} \\
\left(\mathrm{B}-\mathrm{B}^{\prime}\right)\end{array}$ & $\begin{array}{l}1999 \text { Chi-Chi, } \\
\text { Taiwan }\end{array}$ & $0.10-0.23$ & 3.5 & 22 & 0.17 & 5.3 & Chu et al. [34]; Özener [19] \\
\hline 17 & Wufeng site B & & $0.05-0.11$ & 10 & 22 & 0.08 & 11.8 & Chu et al. [34]; Özener [19] \\
\hline 18 & Nantou Site N & & $0.16-0.23$ & 9 & 16.45 & 0.20 & 10.4 & Chu et al. [34]; Özener [19] \\
\hline 19 & Norswig drive & 2003 San & $0.16-0.11$ & 7.2 & 5 & 0.14 & 7.7 & $\begin{array}{c}\text { Olson and Johnson [2]; } \\
\text { Özener [19] }\end{array}$ \\
\hline 20 & Juanita Avenue & Simeon & $0.03-0.10$ & 9.2 & 5 & 0.07 & 9.7 & $\begin{array}{c}\text { Olson and Johnson [2]; } \\
\text { Özener [19] }\end{array}$ \\
\hline 21 & $\begin{array}{c}\text { Snow River } \\
\text { Bridge }\end{array}$ & 1964 Alaska & 0.02 & $5-10$ & $10-30$ & 0.02 & 9.2 & Özener [19] \\
\hline 22 & Juvenile Hall & $\begin{array}{l}1971 \text { San } \\
\text { Fernando }\end{array}$ & $0.02-0.08$ & 6.9 & 35 & 0.05 & 9.7 & $\begin{array}{l}\text { Bennett [35]; Olson and } \\
\text { Johnson [2]; Özener [19] }\end{array}$ \\
\hline
\end{tabular}


TABle 2: Continued.

\begin{tabular}{|c|c|c|c|c|c|c|c|c|}
\hline $\begin{array}{l}\text { Case } \\
\text { no. }\end{array}$ & $\begin{array}{l}\text { Location of } \\
\text { lateral spreading }\end{array}$ & $\begin{array}{l}\text { Earthquake } \\
\text { event }\end{array}$ & $\begin{array}{l}\text { Residual } \\
\text { shear } \\
\text { strength } \\
\text { ratio }\end{array}$ & $\begin{array}{l}\text { SPT } \\
\text { blow } \\
\text { count }\end{array}$ & $\begin{array}{l}\text { Fines } \\
\text { content } \\
(\%)\end{array}$ & $\begin{array}{l}\text { Median } \\
\text { residual } \\
\text { shear } \\
\text { strength } \\
\text { ratio }\end{array}$ & $\begin{array}{l}\text { Equivalent } \\
\text { clean sand } \\
\text { blow count }\end{array}$ & Reference \\
\hline 23 & $\begin{array}{l}\text { Whiskey Sprins } \\
\text { Fan }\end{array}$ & $\begin{array}{l}1983 \text { Borah } \\
\text { Peak }\end{array}$ & $0.05-0.12$ & 13.0 & 22 & 0.08 & 14.8 & $\begin{array}{l}\text { Andrus and Youd [36]; } \\
\text { Olson and Johnson [2]; } \\
\text { Ozener [19] }\end{array}$ \\
\hline 24 & $\begin{array}{l}\text { Landing Road } \\
\text { Bridge }\end{array}$ & & $0.01-0.1$ & $5-10$ & $8-18$ & 0.06 & 8.7 & $\begin{array}{l}\text { Olson and Johnson [2]; } \\
\text { Ozener [19] }\end{array}$ \\
\hline 25 & $\begin{array}{c}\text { James Street } \\
\text { Loop }\end{array}$ & Edgecumbe, & $0.01-0.09$ & $4.8-9.2$ & 10 & 0.05 & 9.5 & $\begin{array}{l}\text { Olson and Johnson [2]; } \\
\text { Özener [19] }\end{array}$ \\
\hline 26 & $\begin{array}{l}\text { Whakatane Pony } \\
\text { Club }\end{array}$ & & $0.02-0.07$ & $3-12$ & $15-18$ & 0.05 & 8.9 & $\begin{array}{l}\text { Olson and Johnson [2]; } \\
\text { Özener [19] }\end{array}$ \\
\hline 27 & $\begin{array}{l}\text { Nalband Railway } \\
\text { Station }\end{array}$ & 1988 Armenia & $0.08-0.10$ & $3.6-23$ & 25 & 0.05 & 15.3 & $\begin{array}{l}\text { Yegian [37]; Olson and } \\
\text { Johnson [2]; Özener [19] }\end{array}$ \\
\hline 28 & Farris Farm & & $0.04-0.13$ & $9-24$ & $5-38$ & 0.09 & 18.3 & $\begin{array}{c}\text { Olson and Johnson [2]; } \\
\text { Özener [19] }\end{array}$ \\
\hline 29 & Leonardini Farm & 1989 Loma & $0.02-0.11$ & 10.0 & $10 \%$ & 0.07 & 11.0 & $\begin{array}{l}\text { Olson and Johnson [2]; } \\
\text { Özener [19] }\end{array}$ \\
\hline 30 & Sea Mist Farm & $\begin{array}{l}\text { Prieta } \\
\text { Prima }\end{array}$ & $0.03-0.08$ & $7-11$ & $16-29$ & 0.06 & 10.8 & $\begin{array}{c}\text { Olson and Johnson [2]; } \\
\text { Özener [19] }\end{array}$ \\
\hline 31 & $\begin{array}{l}\text { Moss Landing, } \\
\text { MLML Bldg., } \\
\text { eastward spread }\end{array}$ & & $0.07-0.12$ & 14.6 & 4 & 0.09 & 15.0 & $\begin{array}{l}\text { Mejia [29]; Olson and } \\
\text { Johnson [2]; Özener [19] }\end{array}$ \\
\hline 32 & $\begin{array}{l}\text { Rudbaneh Town } \\
\text { Canal }\end{array}$ & $\begin{array}{l}1990 \text { Manjil, } \\
\text { Iran }\end{array}$ & $0.05-0.19$ & 8.63 & 4.6 & 0.12 & 9.1 & $\begin{array}{l}\text { Ishihara et al. [38]; Yegian } \\
\text { et al. [39]; Olson and } \\
\text { Johnson [2]; Özener [19] }\end{array}$ \\
\hline 33 & $\begin{array}{l}\text { Magsaysay } \\
\text { Bridge E. Bank, } \\
\text { u/s (AA) }\end{array}$ & & $0.02-0.08$ & $2-9$ & $20-30$ & 0.05 & 7.5 & $\begin{array}{c}\text { Ishihara et al. [40]; Olson } \\
\text { and Johnson [2]; Özener } \\
{[19]}\end{array}$ \\
\hline 34 & $\begin{array}{l}\text { Nable Street } \\
\text { West (B-B) }\end{array}$ & 1990 Luzon, & $0.03-0.09$ & $4.2-10$ & $17.5-27.5$ & 0.06 & 8.9 & $\begin{array}{c}\text { Ishihara et al. [40]; Olson } \\
\text { and Johnson [2]; Özener } \\
{[19]}\end{array}$ \\
\hline 35 & $\begin{array}{l}\text { Nable Street } \\
\text { West }(\mathrm{C}-\mathrm{C})\end{array}$ & Philippines & $0.02-0.07$ & $4-8.5$ & $10-20$ & 0.05 & 7.6 & $\begin{array}{c}\text { Ishihara et al. [40]; Olson } \\
\text { and Johnson [2]; Özener } \\
{[19]}\end{array}$ \\
\hline 36 & $\begin{array}{l}\text { Pogo Chico W. } \\
\text { Bank }\end{array}$ & & $0.03-0.10$ & $6-11$ & $11.3-20$ & 0.07 & 9.9 & $\begin{array}{c}\text { Ishihara et al. [40]; Olson } \\
\text { and Johnson [2]; Özener } \\
{[19]}\end{array}$ \\
\hline 37 & Balboa Blvd. & & $0.11-0.19$ & 17.0 & 52 & 0.15 & 21.0 & Holzer et al. [41] \\
\hline 38 & Wynne Avenue & $\begin{array}{l}1994 \\
\text { Northridge }\end{array}$ & $0.09-0.20$ & 11.6 & 33 & 0.15 & 14.2 & $\begin{array}{c}\text { Holzer et al. [41]; Olson } \\
\text { and Johnson [2]; Idriss and } \\
\text { Boulanger [27]; Özener } \\
\text { [19] }\end{array}$ \\
\hline 39 & Potrero Canyon & & $0.09-0.21$ & $5-17$ & $39-75$ & 0.15 & 15.28 & $\begin{array}{l}\text { Lumbantoruan [42]; } \\
\text { Özener [19] }\end{array}$ \\
\hline 40 & $\begin{array}{l}\text { Seymen Tea } \\
\text { Garden }\end{array}$ & 1999 Kocaeli, & $0.04-0.08$ & $6-12$ & $20-40$ & 0.06 & 11.4 & $\begin{array}{l}\text { Lumbantoruan [42]; } \\
\text { Özener [19] }\end{array}$ \\
\hline 41 & Esme Nose & Turkey & $0.06-0.11$ & $5-13$ & $10-30$ & 0.09 & 10.33 & $\begin{array}{c}\text { Lumbantoruan [42]; } \\
\text { Özener [19] }\end{array}$ \\
\hline 42 & Wufeng site $\mathrm{C} 1$ & 1999 Chi-Chi, & $0.10-0.18$ & $11-18$ & 22 & 0.14 & 16.3 & $\begin{array}{l}\text { Olson and Johnson [2]; } \\
\text { Chu et al. [34]; Özener [19] }\end{array}$ \\
\hline 43 & Wufeng site $M$ & Taiwan & $0.07-0.15$ & 11.5 & 12 & 0.11 & 12.6 & $\begin{array}{l}\text { Olson and Johnson [2]; } \\
\text { Chu et al. [34]; Özener [19] }\end{array}$ \\
\hline
\end{tabular}

$$
\mathrm{MSE}=\frac{1}{M} \sum_{i=1}^{M}\left(y_{i}-\widehat{y}_{i}\right)^{2},
$$

where MSE is the mean squared error between the target value and output value generated by the neural network, $M$ is the number of observations, $y_{i}$ is the target value, and $\widehat{y}_{i}$ is the output value generated by the neural network.

It can be seen from Figure 2 that the data of the predicted residual shear strength ratio lie within the range of $85 \%$ prediction. Figure 3 shows the cumulative probability of the 


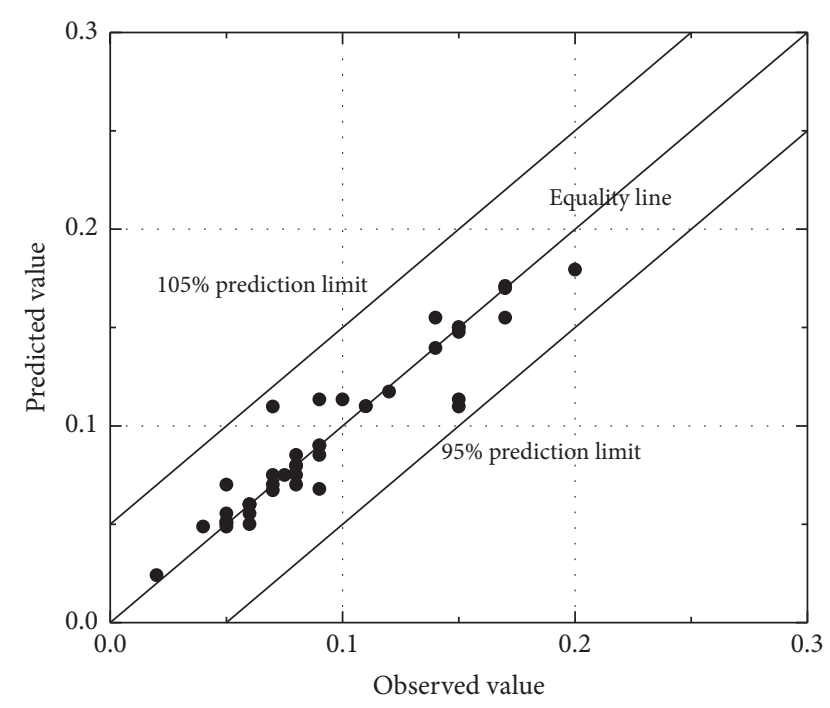

FIgURE 2: The observed and predicted values of residual shear strength ratio.

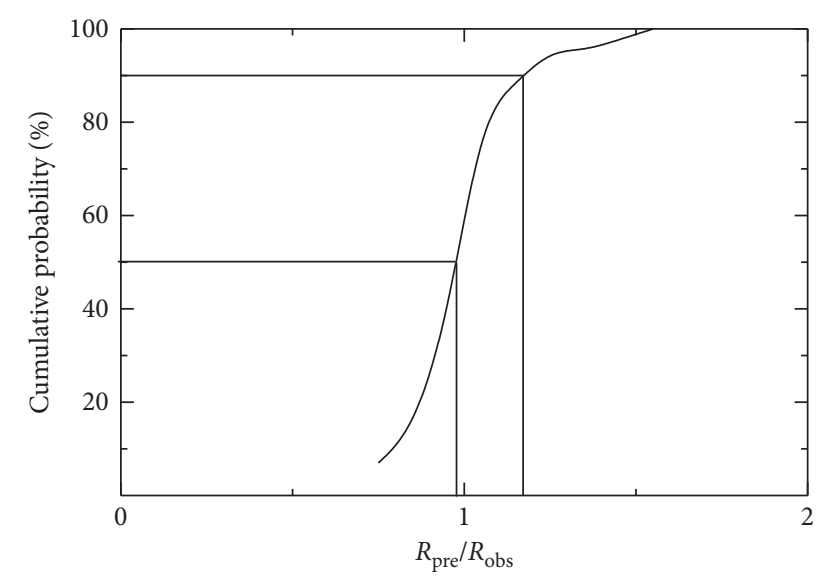

Figure 3: Cumulative probability of the ratio $\left(R_{\text {pre }} / R_{\text {obs }}\right)$ for Artificial Neural Network model.

ratio of the predicted residual shear strength to the observed residual shear strength for the Artificial Neural Network model, where $R_{\text {obs }}$ is the observed residual shear strength ratio and $R_{\text {pre }}$ is the predicted the residual shear strength ratio. The $50 \%$ cumulative probability is close to 1.0 , and the $90 \%$ cumulative probability is 1.15 , which is less than 1.5 ; thus, the model shows slight underestimation at $50 \%$ probability, and the value of the residual shear strength ratio at $90 \%$ probability indicates a small variance for the total predictions.

2.2. Prediction Comparison. Olson and Johnson [2] proposed an estimation method that was used to describe the relationship between the residual shear strength ratio (the ratio of residual shear strength to overburden stress) and the SPT blow count of the liquefied sand based on lateral spreading case histories. As shown in equation (6), $S_{u}$ is the mobilized strength (i.e., residual shear strength), $\sigma_{\mathrm{v}}^{\prime}$ is the prefailure vertical effective stress (i.e., effective overburden stress), and $\left(N_{1}\right)_{60}$ is the SPT blow count of the liquefied sand. In the empirical model proposed by Olson and Johnson [2], the fines content was not considered for calculating residual shear strength ratio, and value of $\left(N_{1}\right)_{60}$ was assumed to be less than 16.0:

$$
\frac{S_{\mathrm{u}}}{\sigma_{\mathrm{v}}^{\prime}}=0.03+0.0075\left[\left(N_{1}\right)_{60}\right] \pm 0.03 .
$$

The predicted residual shear strength using the Artificial Neural Network model was compared with the median residual shear strength ratio by the Olson and Johnson estimation method [2]. Figure 4 shows the predicted residual shear strength ratios by the two methods. To show the variance of the predicted residual shear strength ratio, the root mean square error (RMSE), expressed in equation (7), is used:

$$
\mathrm{RMSE}=\frac{1}{M} \sum_{i=1}^{M} y_{i}-x_{i}^{2},
$$

where RMSE is the root mean square error between the target value and output value of prediction, $M$ is the number of observations, $y_{i}$ is the target value, and $x_{i}$ is the output value of prediction.

The root mean square errors (RMSE) are 0.0783 and 0.0697 for Olson and Johnson estimation method [2] and the Artificial Neural Network model, respectively. The smaller root mean square error (RMSE) from the Artificial Neural Network model indicates a better prediction is made by the Artificial Neural Network model.

2.3. Newmark Displacement of Lateral Spreading Using Residual Shear Strength. The Newmark sliding block method, which was proposed by Newmark [43], has been widely used in evaluating the permanent displacement of slopes, embankments, and landfills. The seismic lateral spreading can be used by the Newmark sliding block method [6-8], in which the soil above the liquefied soil is regarded as a perfect rigid sliding block and the yield acceleration is calculated based on the limit equilibrium analysis. The block is sliding at the constant yield acceleration. The displacement of lateral spreading begins to accumulate when the acceleration of the ground soil above the liquefied soil is greater than the yield acceleration. Once the relative velocity of the ground soil to the sliding surface, which is corresponding with the liquefied soil layer, equals to zero, the displacement of lateral spreading stops to accumulate.

The residual shear strength is the minimum shear strength that is corresponding to the worst-case scenario, so the use of residual shear strength can evaluate the postliquefaction stability of soil deposits for lateral spreading and determine the magnitude of lateral spreading induced by liquefaction. In this section, the residual shear strength is predicted by the Artificial Neural Network model and used in the yield acceleration calculation, which is calculated by the limit equilibrium method. The lateral spreading is calculated by the Newmark sliding block method using the 


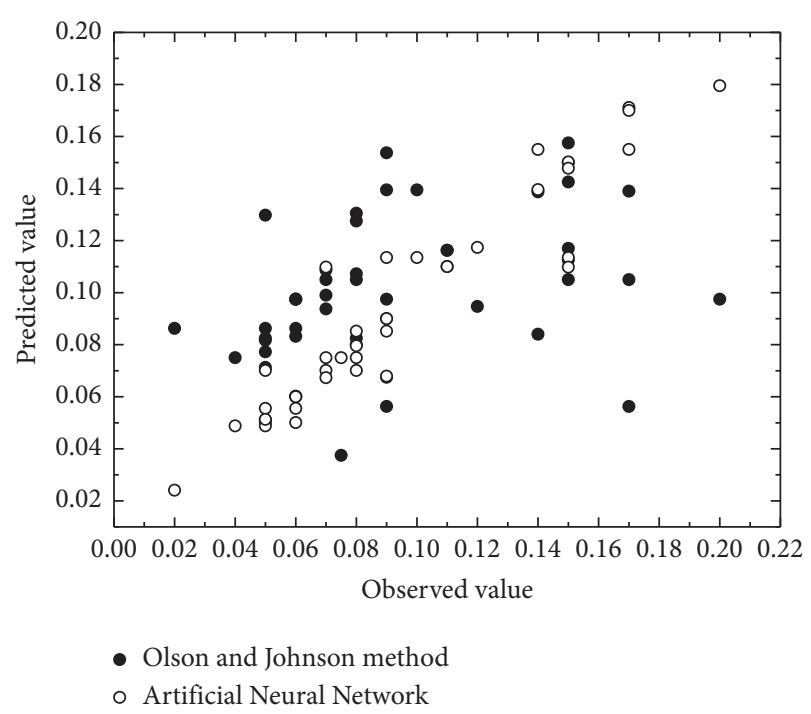

FIgURE 4: The predicted values by Artificial Neural Network model and Olson and Johnson method [2].

postliquefaction yield acceleration corresponding to the residual shear strength of liquefied soil.

The high-quality case histories of lateral spreading are used to apply the Newmark sliding block method. Among the 43 case histories that are used for training the Artificial Neural Network model, the case histories with detailed site investigation and available earthquake motions are classified into the group of high-quality case histories. A total number of 23 case histories grouped as high-quality case histories are selected from Table 2 when the SPT blow count of liquefied soil, the thickness of liquefied soil, the soil profiles, soil classifications, and site-specific earthquake motions or the earthquake motions close to the site are recorded or are available in the research literature. Applying the Morgenstern-Price method, two-dimensional soil profile and the residual shear strength of liquefied soil are used in the limit equilibrium method to obtain the postliquefaction yield acceleration. The soil parameters for the nonliquefiable soil used in the limit equilibrium analysis are based on the soil classifications and reasonable values for different types of soil are assigned. In Table 3, the case histories used in the Newmark sliding block method, the PGA of the site, the effective stress, the residual shear strength of the liquefied soil predicted by the Artificial Neural Network model, and the corresponding yield acceleration from limit equilibrium method are listed for each case history. The average predicted lateral spreading for each case using the motions is also listed in Table 3. Table 4 lists the calculated lateral spreading based on the Newmark sliding block analysis and for each case history using different earthquake motions. In Table 4, the normal displacement and inverse displacement are representing the displacements for each case when the two different directions of the motion were used.

To illustrate the calculation process of applying the Newmark sliding block method in calculating lateral spreading, the case history of Treasure Island was analyzed and shown in the paper. The Treasure Island is a manmade island created by hydraulically placing sand fill over soft sedimentary deposits. Sand boils and ground cracks induced by liquefaction were observed at the site. In Figure S1, the cross section of the subsurface used in the limit equilibrium analysis is shown. The recorded lateral spreading was $0.25 \mathrm{~m}$ based on Power et al. [31]. The laboratory tests were conducted on the samples from the drilled boreholes and Cone Penetration Resistance Test was conducted. The site consisted of four layers of soil from the ground surface to the bottom layer: hydraulically placed sand fill, native Yerba Buena shoals sand and clay, bay mud, and older bay sedimentary deposits. The sand fill was poorly graded silty sand with clayey sand zones. The sand fill was underlain by Yerba Buena shoals which were clayey sand with clay layers and had similar engineering characteristics to sand fill. Both the sand fill and shoal sand were loose and susceptible to the liquefaction under the earthquake. During the earthquake, the sand fill was found to liquefy. Below the Yerba Buena shoals sand, the bay mud consisted of soft to stiff olive-gray silty clay and the older bay sedimentary deposits consisted of brownish and greenish-gray, very stiff sandy, silty, and peaty clay and dense sand, which were insusceptible to lateral movements or settlements. The bay mud was normally consolidated and the strength was increased by the overburden from sand fill and shoals. The groundwater table was affected by tidal fluctuations. $\left(N_{1}\right)_{60}$ of the liquefiable soil on the island was between 5 and 15 blows/ft, so a median of 10.0 and a fines content of $10 \%$ were used to estimate the residual shear strength. Based on the effective stress of $43.99 \mathrm{kPa}$ and the equivalent clean sand corrected SPT blow count of 11.0, the residual shear strength for the liquefied soil is $4.83 \mathrm{kPa}$. The soil parameters for nonliquefiable soil and the liquefied soil used to calculate the postliquefaction yield acceleration are listed in Table S1. A postliquefaction acceleration of $0.052 \mathrm{~g}$ was obtained for the Treasure Island case based on the limit equilibrium analysis, as shown in Figure S2.

The peak acceleration was estimated to be $0.16 \mathrm{~g}$; two motions recorded at Yerba Buena Island from PEER (Pacific Earthquake Engineering Research Center) database [45] were used to calculate the lateral spreading induced by seismic liquefaction. The PGAs of the two motions were scaled to $0.16 \mathrm{~g}$ to conduct the Newmark sliding block analyses. The site classification of the soil where the strongmotion station was located was Class E, of which the shear wave velocity was less than $180 \mathrm{~m} / \mathrm{s}$ based on NEHRP site classification [46]. The average displacement for the Treasure Island case is listed in Table 3 and calculated lateral spreading is listed in Table 4 . The normal and inverse displacement represents the two displacements corresponding to two directions of the input motion. In Figure S3, the Newmark displacements using the two motions are plotted. Figure S3(a) showed the variation of normal-direction displacement versus time and Figure S3(b) showed the variation of inverse-direction displacement versus time for the Treasure Island case. The average lateral spreading was $0.13 \mathrm{~m}$, which was $52 \%$ of the recorded lateral spreading. Table S2 lists the earthquake motions used in the Newmark sliding block analysis. In Table S2, there are 41 total motions used for the analyses, which were available in the motion 
TABLE 3: The average predicted and recorded lateral spreading for each case history.

\begin{tabular}{|c|c|c|c|c|c|c|c|c|c|c|}
\hline Case & Site location & $\begin{array}{c}\text { Earthquake } \\
\text { event }\end{array}$ & $\begin{array}{c}\text { PGA } \\
(\mathrm{g})\end{array}$ & $\begin{array}{c}\text { Effective } \\
\text { stress } \\
(\mathrm{kPa})\end{array}$ & $\begin{array}{l}\text { Residual } \\
\text { shear } \\
\text { strength } \\
(\mathrm{kPa})\end{array}$ & $\begin{array}{c}\text { Yield } \\
\text { acceleration } \\
\text { (g) }\end{array}$ & $\begin{array}{l}\text { Predicted } \\
\text { lateral } \\
\text { spreading } \\
(\mathrm{m})\end{array}$ & $\begin{array}{l}\text { Recorded } \\
\text { lateral } \\
\text { spreading } \\
(\mathrm{m})\end{array}$ & $\begin{array}{l}\text { Displacement } \\
\text { ratio }\end{array}$ & Reference \\
\hline 1 & Juvenile hall & $\begin{array}{c}\text { San } \\
\text { Fernando } \\
(1971)\end{array}$ & 0.7 & 86.56 & 5.80 & 0.06 & 1.72 & 1.5 & 1.15 & Bennett [35] \\
\hline 2 & Heber road & $\begin{array}{c}\text { Imperial } \\
\text { Valley (1979) }\end{array}$ & 0.8 & 61.97 & 4.65 & 0.03 & 1.68 & 2.1 & 0.80 & $\begin{array}{c}\text { Castro [23]; } \\
\text { Youd and } \\
\text { Bennett [24] }\end{array}$ \\
\hline 3 & $\begin{array}{l}\text { Whiskey } \\
\text { Springs fan }\end{array}$ & $\begin{array}{c}\text { Borah Peak } \\
\text { (1983) }\end{array}$ & 0.6 & 107.41 & 8.38 & 0.023 & 1.50 & 0.75 & 2.00 & $\begin{array}{c}\text { Andrus and } \\
\text { Youd [36] }\end{array}$ \\
\hline 4 & Wildlife site & $\begin{array}{l}\text { Superstition } \\
\text { Hills (1987) }\end{array}$ & 0.21 & 61.65 & 4.62 & 0.01 & 1.70 & 0.18 & 9.44 & $\begin{array}{c}\text { Holzer et al. } \\
\text { [25]; } \\
\text { Boulanger } \\
\text { et al. [26]; } \\
\text { Idriss and } \\
\text { Boulanger } \\
\text { [27] }\end{array}$ \\
\hline 5 & $\begin{array}{c}\text { Moss } \\
\text { Landing } \\
\text { Bldg. } 4\end{array}$ & $\begin{array}{c}\text { Loma Prieta } \\
\text { (1989) }\end{array}$ & 0.25 & 63.73 & 10.90 & 0.11 & 0.05 & 0.28 & 0.18 & $\begin{array}{l}\text { Boulanger } \\
\text { et al. [28] }\end{array}$ \\
\hline 6 & $\begin{array}{l}\text { Moss } \\
\text { Landing } \\
\text { Bldg. } 3\end{array}$ & $\begin{array}{c}\text { Loma Prieta } \\
\text { (1989) }\end{array}$ & 0.25 & 84.03 & 16.05 & 0.10 & 0.07 & 0.25 & 0.28 & $\begin{array}{l}\text { Boulanger } \\
\text { et al. [28] }\end{array}$ \\
\hline 7 & $\begin{array}{l}\text { MLML } \\
\text { eastward } \\
(\mathrm{A}-\mathrm{A})\end{array}$ & $\begin{array}{c}\text { Loma Prieta } \\
\text { (1989) }\end{array}$ & 0.25 & 71.87 & 8.19 & 0.08 & 0.11 & 0.45 & 0.24 & Mejia [29] \\
\hline 8 & $\begin{array}{c}\text { MLML } \\
\text { eastward } \\
(\mathrm{B}-\mathrm{B})\end{array}$ & $\begin{array}{c}\text { Loma Prieta } \\
\text { (1989) }\end{array}$ & 0.25 & 139.86 & 15.94 & 0.14 & 0.02 & 0.45 & 0.04 & Mejia [29] \\
\hline 9 & $\begin{array}{l}\text { Leonardini } \\
\text { Farm }\end{array}$ & $\begin{array}{c}\text { Loma Prieta } \\
\text { (1989) }\end{array}$ & 0.16 & 29.97 & 4.92 & 0.23 & N.A. & 0.25 & N.A. & $\begin{array}{c}\text { Charlie et al } \\
\text { [44] }\end{array}$ \\
\hline 10 & $\begin{array}{c}\text { Treasure } \\
\text { Island }\end{array}$ & $\begin{array}{c}\text { Loma Prieta } \\
\text { (1989) }\end{array}$ & 0.16 & 43.99 & 4.83 & 0.052 & 0.13 & 0.25 & 0.52 & $\begin{array}{c}\text { Power et al. } \\
\text { [31] }\end{array}$ \\
\hline 11 & $\begin{array}{l}\text { Rudbaneh } \\
\text { Town Canal }\end{array}$ & $\begin{array}{c}\text { Manjil, Iran } \\
\text { (1990) }\end{array}$ & 0.15 & 232.52 & 27.30 & 0.05 & 0.70 & 1.0 & 0.70 & $\begin{array}{c}\text { Yegian et al. } \\
\text { [39] }\end{array}$ \\
\hline 12 & $\begin{array}{c}\text { Balboa } \\
\text { Blvd. }\end{array}$ & $\begin{array}{c}\text { Northridge } \\
\text { (1994) }\end{array}$ & 0.85 & 109.12 & 16.37 & 0.16 & 0.64 & 0.5 & 1.28 & $\begin{array}{c}\text { Holzer et al. } \\
{[41]}\end{array}$ \\
\hline 13 & Wynne Ave & $\begin{array}{l}\text { Northridge } \\
\text { (1994) }\end{array}$ & 0.51 & 124.28 & 18.64 & 0.168 & 0.16 & 0.15 & 1.07 & $\begin{array}{c}\text { Holzer et al. } \\
\text { [41]; Olson } \\
\text { and Johnson } \\
\text { [2]; Idriss } \\
\text { and } \\
\text { Boulanger } \\
\text { [27] }\end{array}$ \\
\hline 14 & $\begin{array}{c}\text { Wufeng site } \\
\text { C (A-A) }\end{array}$ & $\begin{array}{l}\text { Chi-Chi, } \\
\text { Taiwan } \\
\text { (1999) }\end{array}$ & 0.81 & 80.18 & 5.45 & 0.09 & 2.43 & 2.05 & 1.19 & $\begin{array}{c}\text { Chu et al. } \\
\text { [34] }\end{array}$ \\
\hline 15 & $\begin{array}{c}\text { Wufeng site } \\
\text { C (B-B) }\end{array}$ & $\begin{array}{l}\text { Chi-Chi, } \\
\text { Taiwan } \\
\text { (1999) }\end{array}$ & 0.81 & 80.81 & 13.74 & 0.30 & 0.09 & 0.49 & 0.18 & $\begin{array}{c}\text { Chu et al. } \\
\text { [34] }\end{array}$ \\
\hline 16 & $\begin{array}{l}\text { Wufeng site } \\
\text { C1 }\end{array}$ & $\begin{array}{l}\text { Chi-Chi, } \\
\text { Taiwan } \\
\text { (1999) }\end{array}$ & 0.81 & 76.79 & 11.90 & 0.12 & 1.41 & 1.24 & 1.14 & $\begin{array}{c}\text { Chu et al. } \\
\text { [34] }\end{array}$ \\
\hline 17 & $\begin{array}{c}\text { Wufeng site } \\
\text { B }\end{array}$ & $\begin{array}{l}\text { Chi-Chi, } \\
\text { Taiwan } \\
\text { (1999) }\end{array}$ & 0.81 & 67.64 & 5.41 & 0.06 & 4.38 & 2.96 & 1.48 & $\begin{array}{c}\text { Chu et al. } \\
\text { [34] }\end{array}$ \\
\hline 18 & $\begin{array}{c}\text { Wufeng site } \\
\text { M }\end{array}$ & $\begin{array}{c}\text { Chi-Chi, } \\
\text { Taiwan } \\
\text { (1999) }\end{array}$ & 0.81 & 59.83 & 6.58 & 0.15 & 0.84 & 1.62 & 0.52 & $\begin{array}{c}\text { Chu et al. } \\
\text { [34] }\end{array}$ \\
\hline
\end{tabular}


TABle 3: Continued.

\begin{tabular}{|c|c|c|c|c|c|c|c|c|c|c|}
\hline Case & Site location & $\begin{array}{l}\text { Earthquake } \\
\text { event }\end{array}$ & $\begin{array}{c}\text { PGA } \\
(\mathrm{g})\end{array}$ & $\begin{array}{c}\text { Effective } \\
\text { stress } \\
(\mathrm{kPa})\end{array}$ & $\begin{array}{l}\text { Residual } \\
\text { shear } \\
\text { strength } \\
(\mathrm{kPa})\end{array}$ & $\begin{array}{c}\text { Yield } \\
\text { acceleration } \\
(\mathrm{g})\end{array}$ & $\begin{array}{l}\text { Predicted } \\
\text { lateral } \\
\text { spreading } \\
(\mathrm{m})\end{array}$ & $\begin{array}{l}\text { Recorded } \\
\text { lateral } \\
\text { spreading } \\
(\mathrm{m})\end{array}$ & $\begin{array}{l}\text { Displacement } \\
\text { ratio }\end{array}$ & Reference \\
\hline 19 & $\begin{array}{c}\text { Nantou Site } \\
\mathrm{N}\end{array}$ & $\begin{array}{l}\text { Chi-Chi, } \\
\text { Taiwan } \\
(1999)\end{array}$ & 0.42 & 30.59 & 5.49 & 0.11 & 0.27 & 0.25 & 1.08 & $\begin{array}{c}\text { Chu et al. } \\
\text { [34] }\end{array}$ \\
\hline 20 & $\begin{array}{c}\text { Hotel } \\
\text { Sapanca }\end{array}$ & $\begin{array}{l}\text { Kocaeli, } \\
\text { Turkey } \\
(1999)\end{array}$ & 0.4 & 35.77 & 5.34 & 0.055 & 1.40 & 2.0 & 0.70 & $\begin{array}{c}\text { Cetin et al. } \\
\text { [33] }\end{array}$ \\
\hline 21 & $\begin{array}{l}\text { Police } \\
\text { station }\end{array}$ & $\begin{array}{l}\text { Kocaeli, } \\
\text { Turkey } \\
(1999)\end{array}$ & 0.4 & 29.73 & 2.53 & 0.02 & 4.44 & 2.4 & 1.85 & $\begin{array}{c}\text { Cetin et al. } \\
\text { [33] }\end{array}$ \\
\hline 22 & Soccer field & $\begin{array}{l}\text { Kocaeli, } \\
\text { Turkey } \\
(1999)\end{array}$ & 0.4 & 43.48 & 3.05 & 0.125 & 0.20 & 1.2 & 0.17 & $\begin{array}{c}\text { Cetin et al. } \\
\text { [33] }\end{array}$ \\
\hline 23 & $\begin{array}{l}\text { Yalova } \\
\text { Harbor }\end{array}$ & $\begin{array}{l}\text { Kocaeli, } \\
\text { Turkey } \\
(1999)\end{array}$ & 0.3 & 82.03 & 12.71 & 0.11 & 0.30 & 0.3 & 1.00 & $\begin{array}{c}\text { Cetin et al. } \\
\text { [33] }\end{array}$ \\
\hline
\end{tabular}

TABLE 4: Summarization of calculated lateral spreading.

\begin{tabular}{|c|c|c|c|c|}
\hline Case no. & Motion name & Normal displacement (m) & Inverse displacement (m) & Observed (m) \\
\hline \multirow{4}{*}{1} & PAS-000 & 1.48 & 1.41 & \multirow{4}{*}{1.50} \\
\hline & PAS-090 & 2.12 & 1.98 & \\
\hline & PDL-120 & 2.63 & 2.47 & \\
\hline & PDL-210 & 0.86 & 0.85 & \\
\hline \multirow{4}{*}{2} & AGR-003 & 1.97 & 1.61 & \multirow{4}{*}{2.10} \\
\hline & BCR-140 & 1.79 & 1.91 & \\
\hline & BCR-230 & 1.82 & 1.62 & \\
\hline & SHP-270 & 1.36 & 1.39 & \\
\hline \multirow{2}{*}{3} & BOR000 & 1.70 & 1.88 & \multirow{2}{*}{0.75} \\
\hline & BOR090 & 1.29 & 1.12 & \\
\hline \multirow{2}{*}{4} & WSM-090 & 1.67 & 1.99 & \multirow{2}{*}{0.18} \\
\hline & WSM-180 & 1.41 & 1.73 & \\
\hline \multirow{6}{*}{5} & GOF-160 & 0.03 & 0.02 & \multirow{6}{*}{0.28} \\
\hline & GOF-250 & 0.01 & 0.01 & \\
\hline & $\mathrm{HCH}-090$ & 0.06 & 0.01 & \\
\hline & $\mathrm{HCH}-180$ & 0.23 & 0.11 & \\
\hline & HDA-165 & 0.02 & 0.04 & \\
\hline & HDA-225 & 0.06 & 0.04 & \\
\hline \multirow{6}{*}{6} & GOF-160 & 0.04 & 0.03 & \multirow{6}{*}{0.25} \\
\hline & GOF-250 & 0.02 & 0.02 & \\
\hline & $\mathrm{HCH}-090$ & 0.07 & 0.01 & \\
\hline & HCH-180 & 0.29 & 0.14 & \\
\hline & HDA-165 & 0.03 & 0.05 & \\
\hline & HDA-225 & 0.07 & 0.05 & \\
\hline \multirow{6}{*}{7} & AND-250 & 0.07 & 0.03 & \multirow{6}{*}{0.45} \\
\hline & AND-340 & 0.07 & 0.04 & \\
\hline & G02-000 & 0.03 & 0.06 & \\
\hline & G02-090 & 0.08 & 0.09 & \\
\hline & $\mathrm{HCH}-090$ & 0.12 & 0.06 & \\
\hline & HCH-180 & 0.45 & 0.24 & \\
\hline \multirow{6}{*}{8} & AND-250 & 0.01 & 0.01 & \multirow{6}{*}{0.45} \\
\hline & AND-340 & 0.01 & 0.01 & \\
\hline & G02-000 & 0.00 & 0.01 & \\
\hline & G02-090 & 0.01 & 0.01 & \\
\hline & HCH-090 & 0.04 & 0.00 & \\
\hline & $\mathrm{HCH}-180$ & 0.08 & 0.05 & \\
\hline
\end{tabular}


TABle 4: Continued.

\begin{tabular}{|c|c|c|c|c|}
\hline Case no. & Motion name & Normal displacement (m) & Inverse displacement (m) & Observed (m) \\
\hline \multirow{4}{*}{9} & G02-000 & 0.00 & 0.00 & \multirow{4}{*}{0.25} \\
\hline & G02-090 & 0.00 & 0.00 & \\
\hline & $\mathrm{HCH}-090$ & 0.00 & 0.00 & \\
\hline & $\mathrm{HCH}-180$ & 0.00 & 0.00 & \\
\hline \multirow{2}{*}{10} & TRI-000 & 0.06 & 0.14 & \multirow{2}{*}{0.25} \\
\hline & TRI-090 & 0.11 & 0.20 & \\
\hline \multirow{2}{*}{11} & MANJIL-188040 & 0.41 & 0.39 & \multirow{2}{*}{1.00} \\
\hline & MANJIL-188310 & 1.11 & 0.86 & \\
\hline \multirow{4}{*}{12} & PAR-L & 0.55 & 0.70 & \multirow{4}{*}{0.50} \\
\hline & PAR-T & 1.13 & 1.05 & \\
\hline & SYL-090 & 0.64 & 0.22 & \\
\hline & SYL-360 & 0.52 & 0.31 & \\
\hline \multirow{5}{*}{13} & CNP-106 & 0.13 & 0.09 & \multirow{5}{*}{0.15} \\
\hline & CNP-196 & 0.12 & 0.19 & \\
\hline & SCE-288 & 0.11 & 0.17 & \\
\hline & STC-090 & 0.08 & 0.09 & \\
\hline & STC-180 & 0.29 & 0.28 & \\
\hline \multirow{2}{*}{14} & TCU065-000 & 3.08 & 2.95 & \multirow{2}{*}{2.05} \\
\hline & TCU065-090 & 2.12 & 1.59 & \\
\hline \multirow{2}{*}{15} & TCU065-000 & 0.14 & 0.16 & \multirow{2}{*}{0.49} \\
\hline & TCU065-090 & 0.08 & 0.00 & \\
\hline \multirow{2}{*}{16} & TCU065-000 & 1.96 & 1.75 & \multirow{2}{*}{1.20} \\
\hline & TCU065-090 & 1.14 & 0.79 & \\
\hline \multirow{2}{*}{17} & TCU065-000 & 5.14 & 4.89 & \multirow{2}{*}{2.96} \\
\hline & TCU065-090 & 3.89 & 3.59 & \\
\hline \multirow{2}{*}{18} & TCU065-000 & 1.27 & 1.05 & \multirow{2}{*}{1.62} \\
\hline & TCU065-090 & 0.65 & 0.39 & \\
\hline \multirow{2}{*}{19} & TCU076-000 & 0.27 & 0.14 & \multirow{2}{*}{0.25} \\
\hline & TCU076-090 & 0.34 & 0.33 & \\
\hline \multirow{2}{*}{20} & YPT-060 & 2.19 & 1.60 & \multirow{2}{*}{2.00} \\
\hline & YPT-330 & 0.87 & 0.94 & \\
\hline \multirow{2}{*}{21} & YPT-060 & 6.26 & 5.98 & \multirow{2}{*}{2.40} \\
\hline & YPT-330 & 3.02 & 2.49 & \\
\hline \multirow{2}{*}{22} & YPT-060 & 0.30 & 0.19 & \multirow{2}{*}{1.20} \\
\hline & YPT-330 & 0.13 & 0.16 & \\
\hline & YPT-060 & 0.48 & 0.28 & \\
\hline 23 & YPT-330 & 0.21 & 0.23 & 0.30 \\
\hline
\end{tabular}

database of PEER (Pacific Earthquake Engineering Research Center). For each motion, the distance from the motion to the site and the site classification are included in Table S2.

For Case 9, the postliquefaction yield acceleration is greater than the reported PGA [44]; thus the analysis was not conducted for this case. The predicted lateral spreading for 11 case histories is greater than that for the observed values, and the ratios of the rest of case histories are larger or equal to 1.0 . The average ratio of the 22 case histories is 1.23 , which indicates that the Newmark sliding displacement of lateral spreading using the residual shear strength overall is greater than the observed lateral spreading. For the case of Wildlife Site, the displacement ratio is 9.44, of which the value may be too large compared to the other case histories. If the Wildlife Site case is not accounted for in the calculation of the average ratio of lateral spreading, the average value for the rest of the 21 case histories is 0.836 , with a standard deviation of 0.56 . Due to the limited case histories, the standard deviation of the lateral spreading ratio is still large. In Figure 5, the predicted lateral spreading and observed lateral spreading are plotted, and the prediction limit lines representing the lateral spreading ratio of 0.5 and 2 are shown, respectively. There are 6 out of the 22 case histories having a lateral spreading ratio less than 0.5 , and 15 out the 22 case histories having a lateral spreading ratio less than 2.0 and greater than 0.5 . The cumulative distribution of the lateral spreading ratio calculated with the Newmark sliding block method can be obtained if the frequency counts of the lateral spreading ratios are obtained and proper distribution relationship is used. As the lateral spreading ratio is always greater than 0.0 , the truncated normal distribution is derived from a normally distributed random variable by defining the range of the random variable. Assume that the range of the lateral spreading is from 0.0 to infinite; when applying a truncated normal distribution to describe the distribution of lateral spreading ratio, a probability of $98 \%$ is obtained if a lateral spreading ratio of 2.0 is expected.

2.4. Fitting Relationship between the Residual Shear Strength Ratio and SPT Value. A fitting curve is proposed to describe the relationship between the residual shear strength ratio 


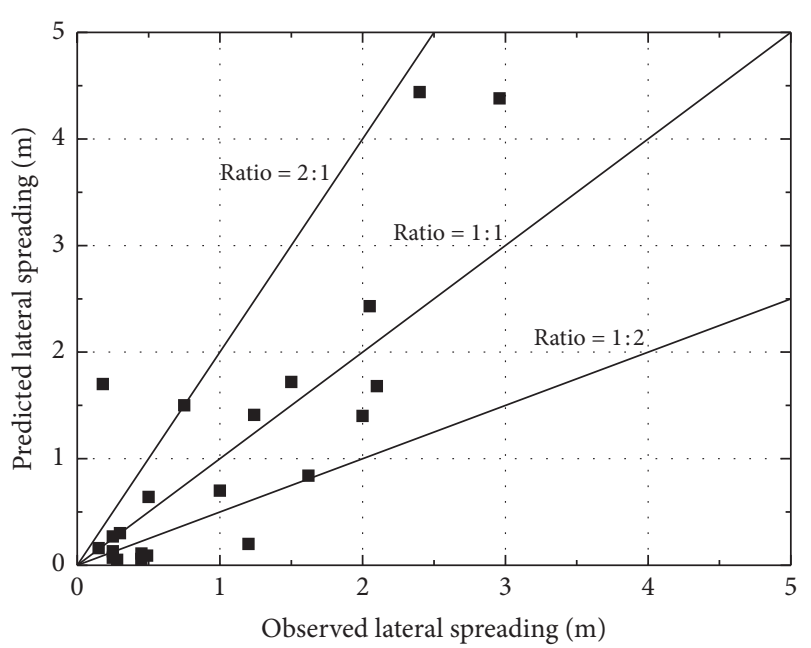

- Predicted lateral spreading

FIGURE 5: Predicted lateral spreading versus observed lateral spreading.

and the equivalent clean sand corrected SPT blow count in Figure 6 . The average value of the residual shear strength ratios is used for the condition that one equivalent clean sand corrected SPT blow count of the liquefied soil is corresponding to various ratios. An exponential function is used to correlate the residual shear strength ratio to equivalent clean sand corrected SPT blow count of liquefied soil. In equation (8), the exponential function used for fitting is shown:

$$
R=\exp \left[0.0004 *\left(N_{1}\right)_{60-\mathrm{cs}}+0.0008 *\left(\left(N_{1}\right)_{60-\mathrm{cs}}\right)^{2}-2.170\right] \text {, }
$$

where $R$ is the residual shear strength ratio, $\left(N_{1}\right)_{60-c s}$ is the equivalent clean sand corrected SPT blow count of the liquefied soil, and the fines content correction values of the SPT blow count are based on values recommend by Seed [1].

\section{Discussion}

Although the residual shear strength ratio was successfully predicted by the Artificial Neural Network model, with a good correlation coefficient for the predicted values, there are still uncertainties that are limiting the further application of Artificial Neural Network. The number of case histories used in the analysis is limited. There are 43 case histories in total in the development of Artificial Neural Network model, and the median values for the residual shear strength ratio and the equivalent clean sand corrected SPT blow count cannot represent the variance of the soil parameters and may induce errors when training Artificial Neural Network model. Furthermore, the value of equivalent clean sand corrected SPT blow count varies when different instruments and testing standards are used.

The nonlinear dynamic response of the sliding mass above the sliding surface has been analyzed by several researchers [47-49], and the effects of the deformable sliding mass and bedrock or the soil below the sliding surface need

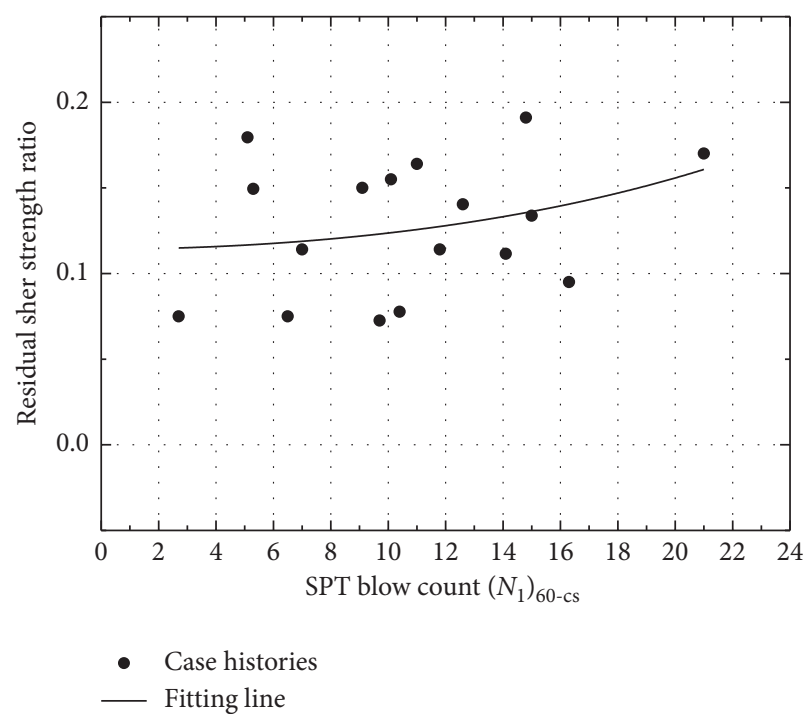

FIGURE 6: The relationship between the residual shear strength ratio and the equivalent clean sand corrected SPT blow count.

to be considered if the displacement of lateral spreading or other Earth structures are desired. Regarding the conventional Newmark sliding block method used in this paper, the intact soil above the liquefied soil is assumed to be a perfectly rigid block, the sliding surface used in the limit equilibrium analysis may not be consistent with the location where the liquefaction occurred, and the deformation of the sliding mass is omitted, so the inaccuracy of the predicted lateral spreading is too attributed to the fact that the dynamic response of the sliding mass is not considered. Moreover, the yield acceleration changes as the inclination (downward movement of sliding mass) decreases [50,51], the change of the geometry for the sliding mass [52] is affecting the yield acceleration, and these two factors can be referred to as the ration effects of the sliding mass. Still, the perfectly-rigid-block assumption of the conventional Newmark sliding block method will yield to a constant yield acceleration, and the omitting of rotation effects of the sliding mass would result in the uncertainty of the lateral spreading and cause the inaccurate predictions. The measurement of the observed lateral spreading reported in the research literature and the ground motions used in the analyses are also contributing to the uncertainties of the predicted lateral spreading.

The Artificial Neural Network model proposed in this paper is providing an insight of the residual shear strength of lateral spreading case histories, while various uncertain factors used in terms of developing the Artificial Neural model need to be paid more attention and the residual shear strength of liquefied soil needs to be used with caution when calculating lateral spreading with Newmark sliding block method.

\section{Conclusions}

The evaluation of lateral spreading induced by liquefaction requires the evaluation of the residual strength of the liquefied soil, but it is difficult to determine the residual shear 
strength of liquefiable soil in engineering practice. In this paper, the residual shear strength ratio of liquefied soil is predicted by the Artificial Neural Network model based on the case histories of lateral spreading. To apply the prediction model of the Artificial Neural Network model, a set of highquality case histories was reanalyzed. The lateral spreading was calculated with Newmark sliding block method and the yield acceleration for each case was calculated with limit equilibrium method using the residual shear strength of liquefied soil predicted by the Artificial Neural Network model. Based on the predictions of residual shear strength ratio predicted by the Artificial Neural Network model and lateral spreading calculated with the Newmark sliding block method, the following conclusions can be drawn.

By taking account of the residual shear strength ratio and the equivalent clean sand corrected SPT blow count of liquefied soil for 43 case histories of lateral spreading, an Artificial Neural Network model was proposed in terms of residual shear strength ratio, the correlation coefficient of the proposed Artificial Neural Network model is 0.92, and the mean squared error (MSE) is 0.001. The value of the residual shear strength ratio at $90 \%$ probability indicates a small variance for the total predictions when applying the proposed Artificial Neural Network model.

Comparing the Artificial Neural Network model to the residual shear strength model by Olson and Johnson, a root mean square error (RMSE) of 0.0697 shows that the proposed Artificial Neural Network model predicts a better ratio compared to Olson and Johnson model, the root mean square error (RMSE) of which is 0.0783 .

The lateral spreading calculated by Newmark sliding block method and the postliquefaction yield acceleration based on the residual shear strength from the proposed Artificial Neural Network model for high-quality case histories show that the average ratio of lateral spreading (the ratio of predicted lateral spreading to observed lateral spreading) is 0.836 , with a standard deviation of 0.56 . When a truncated normal distribution is used to describe the distribution of lateral spreading ratio, the confidence level with a probability of $98 \%$ is obtained if a lateral spreading ratio of 2.0 is expected. Based on the high-quality case histories, an exponential fitting curve is proposed to describe the relationship between the residual shear strength ratio and the equivalent clean sand corrected SPT blow count.

\section{Data Availability}

The data used to support the findings of this study are included within the article.

\section{Conflicts of Interest}

The authors declare that there are no conflicts of interest regarding the publication of this paper.

\section{Acknowledgments}

The authors would like to acknowledge CSC (China Scholarship Council (Grant no. 201407000019)) for its financial support and thank Professor Kavazanjian at Arizona State University for guidance.

\section{Supplementary Materials}

Figure S1: cross section of the subsurface used in the limit equilibrium analysis. Figure S2: limit equilibrium analysis of post-liquefaction yield acceleration. Figure S3: Newmark displacement using the two motions: (a) variation of normal-direction displacement versus time; (b) variation of inverse-direction displacement versus time. Table S1: soil parameters used in the limit equilibrium analysis of postliquefaction yield acceleration. Table S2: earthquake motions used for each case history. (Supplementary Materials)

\section{References}

[1] H. B. Seed, "Design problems in soil liquefaction," Journal of Geotechnical Engineering, vol. 113, no. 8, pp. 827-845, 1987.

[2] S. M. Olson and C. I. Johnson, "Analyzing liquefaction-induced lateral spreads using strength ratios," Journal of Geotechnical and Geoenvironmental Engineering, vol. 134, no. 8, pp. 1035-1049, 2008.

[3] M. H. Hassoun, Fundamentals of Artificial Neural Networks, MIT Press, Cambridge, MA, USA, 1995.

[4] W. S. Noble, "What is a support vector machine?" Nature Biotechnology, vol. 24, no. 12, pp. 1565-1567, 2006.

[5] J. R. Koza, Genetic Programming, MIT Press Cambridge, Cambridge, MA, USA, 1994.

[6] M. H. Baziar, R. Dobry, and A. W. Elgamal, "Engineering evaluation of permanent ground deformations due to seismically induced liquefaction," Technical Report NCEER-920007, p. 269, National Center for Earthquake Engineering Research, Buffalo, NY, USA, 1992.

[7] V. M. Taboada, T. Abdoun, and R. Dobry, "Prediction of liquefaction-induced lateral spreading by dilatant sliding block model calibrated by centrifuge tests," in Proceedings of the 11th World Conf. On Earthquake Engineering, Pergamon Oxford, UK, 1996.

[8] National Academies of Sciences, Engineering, and M. State of the Art and Practice in the Assessment of Earthquake-Induced Soil Liquefaction and its Consequences, The National Academies Press, Washington, DC, USA, 2016.

[9] Rocscience, Slide v5.0-2D limit equilibrium slope Stability Analysis, Rocscience Inc, Toronto, Canada, 2005.

[10] R. W. Jibson, E. M. Rathje, M. W. Jibson, and Y. W. Lee, SLAMMER: Seismic Landslide Movement Modeled Using Earthquake Records, US Geological Survey, Reston, VA, USA, 2013.

[11] H. B. Seed, R. B. Seed, L. F. Harder, and H. L. Jong, "Reevaluation of the slide in the Lower San Fernando Dam in the 1971 San Fernando earthquake," WES Contract Report GL89-2, United States Army Corps of Engineers, Vicksburg, MS, USA, 1998.

[12] I. M. Idriss, "Evaluation of liquefaction potential, consequences and mitigation an update," in Proceedings of the Presentation Notes for Geotechnical Society Meeting, Vancouver, Canada, February 1998.

[13] T. D. Stark and G. Mesri, "Undrained shear strength of liquefied sands for stability analysis," Journal of Geotechnical Engineering, vol. 118, no. 11, pp. 1727-1747, 1992. 
[14] S. M. Olson and T. D. Stark, "Liquefied strength ratio from liquefaction flow failure case histories," Canadian Geotechnical Journal, vol. 39, no. 3, pp. 629-647, 2002.

[15] I. M. Idriss and R. W. Boulanger, "SPT-and CPT-based relationships for the residual shear strength of liquefied soils," in Earthquake geotechnical engineering, K. D. Pitilakis, Ed., vol. 6, pp. 1-22, Springer, Dordrecht, Netherland, 2007.

[16] I. M. Idriss and R. W. Boulanger, "Lecture: 2nd Ishihara lecture: SPT- and CPT-based relationships for the residual shear strength of liquefied soils," Soil Dynamics and Earthquake Engineering, vol. 68, pp. 57-68, 2015.

[17] S. L. Kramer, "Evaluation of liquefaction hazards in Washington state," Washington State Department of Transportation, Office of Research and Library Services, Washington, DC, USA, WA-RD 668.1, 2008.

[18] S. L. Kramer and C.-H. Wang, "Empirical model for estimation of the residual strength of liquefied soil," Journal of Geotechnical and Geoenvironmental Engineering, vol. 141, no. 9, p. 04015038, 2015.

[19] P. Özener, "Estimation of residual shear strength ratios of liquefied soil deposits from shear wave velocity," Earthquake Engineering and Engineering Vibration, vol. 11, no. 4, pp. 461-484, 2012.

[20] M. H. Beale, M. T. Hagan, and H. B. Demuth, Neural Network Toolbox, pp. 77-81, MathWorks Inc, Natick, MA, USA, 2010.

[21] E. Sariev and G. Germano, "Bayesian regularized artificial neural networks for the estimation of the probability of default," Quantitative Finance, vol. 20, no. 2, pp. 311-328, 2020.

[22] A. P. Davis Jr., S. J. Poulos, and G. Castro, "Strengths backfigured from liquefaction case histories," in Proceedings of the Second International Conference on Case Histories in Geotechnical Engineering, Missouri University of Science and Technology (formerly the University of Missouri-Rolla), St. Louis, MI, USA, June 1988.

[23] G. Castro, "Empirical methods in liquefaction evaluation," in Proceedings of the Proceedings of the 1st Annual Leonardo Zeevaert International Conference, vol. 1, pp. 1-41, Mexico City, Mexico, 1995.

[24] T. L. Youd and M. J. Bennett, "Liquefaction sites, imperial valley, California," Journal of Geotechnical Engineering, vol. 109, no. 3, pp. 440-457, 1983.

[25] T. L. Holzer, T. C. Hanks, and T. L. Youd, "Dynamics of liquefaction during the 1987 superstition hills, California, earthquake," Science, vol. 244, no. 4900, pp. 56-59, 1989.

[26] R. W. Boulanger, D. W. Wilson, and I. M. Idriss, "Examination and reevalaution of spt-based liquefaction triggering case histories," Journal of Geotechnical and Geoenvironmental Engineering, vol. 138, no. 8, pp. 898-909, 2012.

[27] I. M. Idriss and R. W. Boulanger, "SPT-based liquefaction triggering procedures," Report No. UCD/CGM-10/02, University of California at Davis, Davis, CA, USA, 2010.

[28] R. W. Boulanger, L. H. Mejia, and I. M. Idriss, "Liquefaction at moss landing during loma prieta earthquake," Journal of Geotechnical and Geoenvironmental Engineering, vol. 123, no. 5, pp. 453-467, 1997.

[29] L. H. Mejia, "Liquefaction at moss landing," Technical Report, pp. 129-150, U.S. Geological Survey Open-File Report 00-444, United States Government Printing Office, Washington, DC, USA, 1998.

[30] T. L. Holzer, J. C. Tinsley, M. J. Bennett, and C. S. Mueller, "Observed and predicted ground deformation-Miller Farm lateral spread, Watsonville, California," vol. 94, Technical Report NCEER, pp. 79-99, US National Center for Earthquake Engineering Research (NCEER), Buffalo, NY, USA, 1994.
[31] M. S. Power, J. A. Egan, M. L. TraubenikF, and J. R. Faris, "Liquefaction at naval station treasure island and design of mitigating measures," Technical Report, pp. 87-121, U. S. Geological Survey Open-File Report 00-444, United States Government Printing Office, Washington, DC, USA, 1998.

[32] K. Ishihara, A. A. Acacio, and I. Towhata, "Liquefaction-induced ground damage in dagupan in the july 16, 1990 Luzon earthquake," Soils and Foundations, vol. 33, no. 1, pp. 133-154, 1993.

[33] K. O. Cetin, T. L. Youd, R. B. Seed et al., "Liquefaction-induced ground deformations at hotel sapanca during kocaeli (izmit),Turkey earthquake," Soil Dynamics and Earthquake Engineering, vol. 22, no. 9-12, pp. 1083-1092, 2002.

[34] D. B. Chu, J. P. Stewart, T. L. Youd, and B. L. Chu, "Liquefaction-induced lateral spreading in near-fault regions during the 1999 Chi-Chi, Taiwan earthquake," Journal of Geotechnical and Geoenvironmental Engineering, vol. 132, no. 12, pp. 1549-1565, 2006.

[35] M. J. Bennett, "Liquefaction analysis of the 1971 ground failure at the san fernando valley juvenile Hall, California," Environmental \& Engineering Geoscience, vol. xxvi, no. 2, pp. 209-226, 1989.

[36] R. D. Andrus and T. L. Youd, "Subsurface investigation of a liquefaction-induced lateral spread, thousand springs valley, Idaho," Master thesis, Brigham Young Univeristy, Provo, UT, USA, 1987.

[37] M. K. Yegian, V. G. Ghahraman, and R. N. Harutiunyan, "Liquefaction and embankment failure case histories, 1988 Armenia earthquake," Journal of Geotechnical Engineering, vol. 120, no. 3, pp. 581-596, 1994.

[38] K. Ishihara, S. M. Haeri, A. A. Moinfar, I. Towhata, and S. Tsujino, "Geotechnical aspects of the june 20, 1990 Manjil earthquake in Iran," Soils and Foundations, vol. 32, no. 3, pp. 61-78, 1992.

[39] M. K. Yegian, V. G. Ghahraman, M. A. A. Nogole-Sadat, and H. Daraie, "Liquefaction during the 1990 Manjil, Iran, earthquake, II: case history analyses," Bulletin of the Seismological Society of America, vol. 85, pp. 83-92, 1995.

[40] K. Ishihara, "Characterization of cyclic behavior of sand and post-seismic stability analyses," in Proceedings of the 9th Asian Regional Conference on Soil Mechanics and Foundation Engineering, Springer, Bangkok, Thailand, December 1991.

[41] T. L. Holzer, M. J. Bennett, D. J. Ponti, and J. C. Tinsley III, "Liquefaction and soil failure during 1994 Northridge earthquake," Journal of Geotechnical and Geoenvironmental Engineering, vol. 125, no. 6, pp. 438-452, 1999.

[42] P. M. H. Lumbantoruan, "Probabilistic postliquefaction residual shear strength analyses of cohesionless soil deposits: application to the Kocaeli (1999) and Duzce (1999) earthquakes," Doctoral thesis, Virginia Polytechnic Institute, Blacksburg, VA, USA, 2005.

[43] N. M. Newmark, "Effects of earthquakes on dams and embankments," Géotechnique, vol. 15, no. 2, pp. 139-160, 1965.

[44] W. A. Charlie, D. O. Doehring, J. P. Brislawn, and H. Hassen, "Direct measurement of liquefaction potential in soils of Monterey County, California," Technical Report, pp. 181-222, U.S. Geological Survey Open-File Report 00-444, Washington, DC, USA, 1998.

[45] Y. Bozorgnia, N. A. Abrahamson, L. A. Atik et al., "NGAWest2 research project," Earthquake Spectra, vol. 30, no. 3, pp. 973-987, 2014.

[46] Building Seismic Safety Council, NEHRP Recommended Seismic Provisions for New Buildings and Other structures, FEMA P-1050-1, p. 750, Federal Emergency Management 
Agency of the U.S. Department of Homeland Security, Washiongton D.C., USA, 2009.

[47] L. C. Katsenis, C. A. Stamatopoulos, V. P. Panoskaltsis, and B. Di, "Prediction of large seismic sliding movement of slopes using a 2-body non-linear dynamic model with a rotating stick-slip element," Soil Dynamics and Earthquake Engineering, vol. 129, p. 105953, 2020.

[48] E. M. Rathje and J. D. Bray, "An examination of simplified earthquake-induced displacement procedures for earth structures," Canadian Geotechnical Journal, vol. 36, no. 1, pp. 72-87, 1999.

[49] G. Tropeano, A. Chiaradonna, A. d'Onofrio, and F. Silvestri, "A numerical model for non-linear coupled analysis of the seismic response of liquefiable soils," Computers and Geotechnics, vol. 105, pp. 211-227, 2019.

[50] Y. Jafarian and A. Lashgari, "Simplified procedure for coupled seismic sliding movement of slopes using displacement-based critical acceleration," International Journal of Geomechanics, vol. 16, no. 4, Article ID 04015101, 2016.

[51] C. A. Stamatopoulos, "Sliding system predicting large permanent co-seismic movements of slopes," Earthquake Engineering \& Structural Dynamics, vol. 25, no. 10, pp. 1075-1093, 1996.

[52] C. A. Stamatopoulos, C. Mavromihalis, and S. Sarma, "Correction for geometry changes during motion of slidingblock seismic displacement," Journal of Geotechnical and Geoenvironmental Engineering, vol. 137, no. 10, pp. 926-938, 2011. 